\title{
Seasonal and spatial variation of species toxicity in Mediterranean seaweed communities: correlation to biotic and abiotic factors
}

\author{
Ruth Martí $^{1, *}$, Maria J. Uriz ${ }^{1}$, Xavier Turon ${ }^{2}$ \\ ${ }^{1}$ Centre d'Estudis Avançats de Blanes (CSIC), Accés Cala Sant Francesc 14, 17300 Blanes (Girona), Spain \\ ${ }^{2}$ Department of Animal Biology, Faculty of Biology, University of Barcelona, Diagonal Ave. 645, 08028 Barcelona, Spain
}

\begin{abstract}
The toxicity of crude extracts of 32 seaweed species from the western Mediterranean was analysed by Microtox ${ }^{\circledR}$ assay in spring and autumn of 1996 and 1997. The species analysed represented more than $76 \%$ of seaweed coverage in the 3 algal communities studied: photophilic and sciaphilic communities from the Cabrera Archipelago (Balearic Islands), and a hemisciaphilic community from the Medes Archipelago (northeastern Iberian Peninsula). Most species showed seasonal variation of toxicity, which was greater in species from Cabrera than in those from Medes. Both, intra and interspecies variation of toxicity were found. Moreover, comparison of mean toxicity of these communities showed that toxicity was higher in November than in June in all cases, and that the photophilic community had both the highest number and the most toxic species. To make an ecologically relevant interpretation of the toxicity detected by Microtox ${ }^{\circledR}$, we compared the toxicity of extracts analysed by the Microtox ${ }^{\circledast}$ test and those analysed by the commonly used sea urchin embryo assay. In addition to seaweeds, some species of invertebrates (sponges and ascidians) were compared to ascertain whether the relationship between the 2 tests was applicable to species belonging to different phyla. These comparisons allowed us to establish that 0.5 gamma units in Microtox ${ }^{\circledR}$ assay is the threshold value between toxic and non-toxic species. Following a light gradient from the photophilic to the sciaphilic communities, the seaweed species that were occasionally toxic increased while the always-toxic seaweeds decreased. Rhodophyta and Phaeophyta had a higher percentage of toxic species than Chlorophyta. Non-encrusting seaweed forms were more toxic than the encrusting ones, and in contrast to most other seaweeds, the non-encrusting calcareous species that increased coverage from June to November simultaneously displayed a marked decrease in toxicity. We conclude that the temporal variation of toxicity observed in the seaweeds studied may be partially explained by intrinsic factors of the species (growth rates and growth shapes).
\end{abstract}

KEY WORDS: Natural toxicity $\cdot$ Seaweed $\cdot$ Seasonal variation $\cdot$ Spatial variation $\cdot$ Microtox ${ }^{\circledR}$ assay $\cdot$ Sea urchin assay $\cdot$ Mediterranean Sea $\cdot$ Growth shapes

\section{INTRODUCTION}

Toxicity screenings of seaweed species from various geographic regions (Caccamese \& Azzolina 1979, Henríquez et al. 1979, Caccamese et al. 1980, Chénieux et al. 1980, Naqvi et al. 1980, Ballesteros et al. 1992) have shown repeatedly that seaweeds are an important source of bioactive products. Consequently, seaweeds have often been targeted in the search for compounds with pharmacological properties. The most common property of seaweed extracts tested is their effectiveness against pathogenic micro-organisms such as bacteria, fungi and viruses.

However, studies to clarify the ecological functions of toxic algal secondary metabolites are scarce and usually focus on just 1 or a few species. Seaweeds and, in general, benthic invertebrates are exposed to variable environmental factors such as light intensity, food 
availability, salinity and pollution concentrations, as well as to biotic pressures such as predation and spatial and trophic competition. All these factors affect the organisms' physiology and have direct effects on the production of seaweed secondary metabolites that can have several functions (Schmitt et al. 1995). Among the different ecological functions reported, the best known (possibly because it is more amenable to experimental manipulation) is the anti-predatory role (Hay et al. 1987, 1988, Meyer \& Paul 1992, Cronin \& Hay 1996, Stachowicz \& Lindquist 1997, Schnitzler et al. 1998, 2001). The anti-fouling activity of algae is less well known (de Nys et al. 1995, Schmitt et al. 1995, Kjelleberg et al. 1997). However, the localization of some bioactive compounds in cells and their release to the seaweeds surface suggest an anti-fouling role (Wolk 1968, Ragan 1976, Ragan \& Glombitza 1986, de Nys et al. 1998, Dworjanyn et al. 1999). The allelochemical function of secondary metabolites from seaweeds has also been postulated (Fletcher 1975, Helleburst 1975, Vadas 1979, Harlin 1987), but evidence of negative effects of these compounds on neighbouring organisms is scarce (de Nys et al. 1991).

The aims of this study were to investigate the relationships of several structural and dynamic descriptors of algal-benthic communities with the seasonal and spatial variation of toxicity in the most abundant species of 3 algal communities from the Mediterranean Sea. These descriptors were species shape (Martí 2002) and seasonal changes in coverage (i.e. as an estimation of growth).

The novelty of the study is the analysis of a high number of species (as in pharmacological-oriented screenings), which are representative of whole communities, thus allowing an interpretation of the results at a community level. The high number of samples analysed made it necessary to use a standardised bioassay such as the Microtox ${ }^{\circledR}$ assay (Becerro et al. 1995, Martí et al. 2003). This assay is highly repeatable and precise, allowing analysis and quantification of the toxicity of a large number of taxonomically diverse species to detect intra and interspecies variation and community-level patterns. Furthermore, it correlates well with many other biological assays (e.g. Botsford 2002). Of course, this method, as with any general test, cannot detect all kind of species toxicity. That is why we are using our data only for comparative purposes to analyse variation in toxicity among individuals, species, communities or seasons.

The relationship between growth shape and survival strategies of algae has been studied by Littler \& Littler (1980) and Littler et al. (1983), who proposed a functional-form hypothesis for benthic marine macroalgae. Here, we have studied whether different growth shapes relate to species toxicity.
It has been suggested that the production of chemical defences is costly in most cases (Cronin 2001). Therefore, organisms have to allocate resources and energy to different activities (i.e. growth, reproduction, defence, e.g. Uriz et al. 1995) for their well-being, which often implies trade-offs in resource allocation from one process to another. In particular, investment in chemical defence may be at odds with investment in growth (Cronin 2001). Thus, in order to examine this trade-off, seasonal changes in coverage were compared to seasonal changes in toxicity for each seaweed species.

Our purpose was to obtain new insights into the role that species toxicity may play in the field, and on the factors that influence the high variation of toxicity found, by using a a previously studied system of 3 communities (Martí et al. 2004) as a case study.

\section{MATERIALS AND METHODS}

Sampling. Samples of 3 algal communities were collected by SCUBA divers from 2 Mediterranean archipelagos in June and November 1996 and 1997. Sampling was performed according to previous inventories of these communities (Martí et al. 2004). The communities studied followed a gradient of light as they were located at the entrance of submarine caves. We selected a photophilic (from 70 to $15 \%$ of superficial light) and a sciaphilic (5 to $1.5 \%$ ) community from the Cabrera Archipelago (Balearic Islands) and a hemisciaphilic (20 to $5 \%$ ) community from the Medes Archipelago (Catalan coast). A more detailed description of these communities and the coverage of every species can be found in Martí et al. (2004). Our communities correspond to what Martí et al. (2004) called Zone 1 and Zone 2 of the Cabrera cave (the photophilic and sciaphilic communities, respectively), and Zone 1 of the Medes cave (the hemisciaphilic community).

Whenever the number of specimens available allowed, 3 replicates of each species were collected, extracted and analysed separately.

Due to the clonal nature of seaweeds, we considered the thalli that were physically contiguous, forming a single patch, as an individual (i.e. same clone) and considered as replicates those thalli collected from patches, which were at least $1 \mathrm{~m}$ apart.

Chemical extraction. Once in the laboratory, samples were cleaned of epibionts, frozen, lyophilised and stored for subsequent chemical extraction. Samples were extracted and analysed directly after collection, in both seasons.

A known weight of each lyophilised sample was extracted 3 successive times in $10 \mathrm{ml}$ of methanol (MeOH) for 5, 10 and $15 \mathrm{~min}$, respectively, using an ultrasonic bath. The solvent from the 3 extractions was filtered, 
pooled and completely evaporated under reduced pressure and a stream of nitrogen. The dry crude extracts were then weighed and kept at $-20 \mathrm{C}^{\circ}$ until dilution in artificial seawater for the Microtox ${ }^{\circledR}$ assay.

Microtox $^{\circledR}$ assay. The Microtox ${ }^{\circledR}$ assay analyses the toxicity of the extracts to a marine abyssal bacterium, Vibrio fisheri. Previous studies have shown that the Microtox ${ }^{\circledR}$ assay has higher precision and sensitivity than other commonly used tests (Becerro et al. 1995, Del Valls et al. 1997, Pedersen et al. 1997, Burridge et al. 1999, Ghirardini et al. 1999, Sabaliunas et al. 2000) and that the toxicity measured with this test correlates well with both chemical quantification (Martí et al. 2003) and many other biological assays (Botsford 2002). These reasons made this assay the preferred choice for our study.

Just before the Microtox ${ }^{\circledR}$ analyses, crude extracts were dissolved in artificial seawater (prepared following Margalef 1977) to obtain a final concentration of $1000 \mu \mathrm{g}$ crude extract $\mathrm{ml}^{-1}$. We used a dilution factor of 2 , and tested concentrations of 500, 250, 125 and $62.5 \mu \mathrm{g} \mathrm{ml}^{-1}$ (i.e. $50,25,12.5$ and $6.25 \%$ of the initial $1000 \mu \mathrm{g} \mathrm{ml}^{-1}$ ).

The toxicity index provided by Microtox is measured in Gamma units, which are calculated as:

$$
\text { Gamma }=\left[\left(I_{0} \times \text { correction factor }\right) I_{t}^{-1}\right]-1
$$

where $I_{0}$ and $I_{t}$ are the bioluminescence measured before and after $5 \mathrm{~min}$ of exposure of bacteria to the crude extract solution or suspension, respectively. The correction factor is the ratio between the initial bioluminescence and that measured after $5 \mathrm{~min}$ in the control wells.

To compare results across samples we used the gamma value corresponding to the concentration of $1 \mathrm{mg}$ sample DW (dry weight) $\mathrm{ml}^{-1}$. The toxicity of this concentration was obtained by using the resulting regression equation of the Microtox ${ }^{\circledR}$ assay (Martí et al. 2003). We chose to use a concentration based upon sample DW (instead of crude extract DW) to make the results comparable in spite of different weights of sample extracted or different proportions of crude extract $\mathrm{g}^{-1} \mathrm{DW}$ across samples. We believe that the ecologically relevant information is the amount of toxicity per sample unit, not per extract unit.

Sea urchin assay. To determine whether species toxicity measured by Microtox ${ }^{\circledR}$ can also extend to marine invertebrates, we compared the Microtox ${ }^{\circledR}$ results with those from the sea urchin assay, which assesses cytotoxic (i.e. number of divided but dead or aberrant embryos) and antimitotic (number of non divided but fertilized embryos) effects of extracts on Paracentrotus lividus embryos (see Martín \& Uriz 1993 for a detailed description of this method). We used the same crude extracts and tested the same concentrations $(500,250$,
125 and $62.5 \mu \mathrm{g} \mathrm{ml}^{-1}$ ) of species belonging to different phyla with both tests. The target species were previously known to have some kind of active metabolites (Martín \& Uriz 1993 and unpubl. data). The seaweed Flabellia petiolata (Turra) Nizamuddin, the sponges Dendroxea lenis (Topsent, 1892) and Axinella damicornis (Esper, 1794) and the tunicate Pseudodistoma cyrnusense Pérès, 1952 were analysed from the Cabrera site. The Medes' species analysed were the seaweeds F. petiolata and Peyssonnelia squamaria (Gmelin) Decaisne, and the sponges Dysidea avara (Schmidt, 1862) and Aplysina aerophoba Schmidt, 1862. The toxicity index (Ti) used for the sea urchin test was $\mathrm{Ti}=1-\left(A_{0} A_{\mathrm{t}}^{-1}\right)$, where $A_{\mathrm{t}}$ and $A_{0}$ are the average percent of aberrant (i.e. irregularly divided and resulting in non-viable embryos) plus non-divided embryos in 3 replicates from treatment (t) and control (0), respectively. This index ranges from 0 (non-toxic) to 1 (no viable embryo).

Qualitative classification of seaweeds depending on their toxicity. The previous step gave the calibration of a threshold for toxicity measurements with the Microtox ${ }^{\circledR}$ assay. This value allowed us to classify the species as toxic or non-toxic. Moreover, we were able to detect shifts from one condition to the other depending on season or on community. The abundance of species that were always toxic, in all communities and seasons (hereafter always-toxic species), those which were never toxic in any community or season (hereafter never-toxic species) and the ones which were toxic only in some community or season (hereafter occasionally toxic species) were scored and compared. We also counted the number of toxic seaweeds in the main taxonomic groups, Chlorophyta, Rhodophyta and Phaeophyta.

Relationship between species toxicity and growth shapes. As for seaweeds, we followed the functionalform groups established by Littler et al. (1983), i.e. crustose group (e.g. Mesophyllum alternans), thick, leathery group (e.g. Cystoseira balearica, Padina pavonica, Flabellia petiolata), sheet group (e.g. Dyctiopteris membranacea) and coarsely branched group (e.g. Halopteris sp.). Afterwards we compared the mean toxicity between encrusting and non-encrusting species (Fig. 7).

Seasonal changes in coverage and toxicity. Twenty photographs of $310 \mathrm{~cm}^{2}$ were randomly taken in each community in June and November. The photographs were projected on an inverse slide projector and the patches of each species were outlined. These outlibe drawings allowed us to record the contacts among the species, but overgrowth processes might not be clearly discernible. By digitalising these photographs and using image analysis we obtained the coverage of each species. The seasonal changes in coverage and toxicity 
were estimated from the formula: Seasonal change of coverage $=$ (coverage in November - coverage in June)/coverage in June.

A similar formula was applied for toxicity by using toxicity values instead of coverage values. This change indicates whether coverage or toxicity increased or decreased (indicated by a plus/minus sign) in November compared to June.

Statistical analyses. Seasonal changes in toxicity were statistically analysed for each species. Student's $t$-test analyses for differences between seasons were performed for species present in only 1 community. Species present in more than 1 community from a single archipelago were analysed by 2-way ANOVA with season and community as factors. To make a comparison between communities, the mean toxicity for species present in both seasons was calculated and compared by 2 -way ANOVA.

Unless otherwise stated, Tukey post-hoc tests were used for a posteriori comparisons. In all cases, when data did not meet the assumptions of normality (Kolmogorov-Smirnov test) and homoscedasticity (Bartlett test), rank transformation was carried out and parametric analyses were performed on ranked data (Conover \& Iman 1981, Potvin \& Roff 1993). All analyses used the Systat v5.0 and Statistica v4.0 packages.

The toxicity indices obtained with the sea urchin assay for all concentrations and samples were related by regression analyses to the gamma units obtained for the corresponding concentrations with the Microtox ${ }^{\circledR}$ test.

Seasonal changes in coverage were plotted against seasonal changes in toxicity. In this plot the species appear divided into 4 groups following graphical representation in quadrants: those that increased or decreased concomitantly coverage and toxicity from June to November (Quadrants II and III, respectively) and those that increased coverage with decreased toxicity or vice-versa (Quadrants I and IV). We tabulated our observations as a 2-way contingency table and used a chi-square goodness of fit analysis with Yates correction for continuity (Zar 1984) to test whether the distribution of the species among quadrants deviated from a random pattern.

\section{RESULTS}

\section{Quantitative approach to seaweed toxicity}

\section{Photophilic and sciaphilic communities from the} Cabrera Archipelago

A total of 25 seaweed species from the 2 Cabrera communities were analysed: 21 species from the photophilic seaweed community and 5 species from the sciaphilic seaweed community (1 species was common to both communities). Some of these seaweeds were not present in both seasons due to seasonal dynamics, which implied changes in structure descriptors of the community and in species coverage (Martí 2002).

In the photophilic community, the analysed species (Table 1) represented 97 and $94 \%$ of seaweed coverage of the zone in June and November, respectively. In the sciaphilic seaweed community (Table 1), these percentages varied from $77 \%$ in June to $84 \%$ in November. Therefore, the samples collected were representative of the phytobenthic communities studied in both sampling seasons.

For the species for which there was replicate samples in both seasons and/or in both communities, the variation in toxicity is shown in Figs. 1 \& 2. Summarizing the results of the statistical tests, we found significantly higher toxicity in Pseudochlorodesmis furcellata during November than in June, whereas for Lobophora variegata we found the opposite pattern. For Corallina elongata and Haliptilon virgatum there was no significant variation.

Among the 12 species without replicates from the photophilic community of Cabrera analysed in both seasons, 11 species $(79 \%)$ showed higher toxicity in November than in June with important seasonal differences. Six of these 11 species (55\%) were toxic in both seasons (Dictyota dichotoma var. intricata, Anadyomene stellata, Dictyopteris polypodioides, Halopteris scoparia, Amphiroa rigida and Valonia utricularis), and 5 species (45\%) (Mesophyllum alternans, Polysiphonia fruticulosa, Cystoseira compressa, Padina pavonica and Neogoniolithon notarisii) were toxic in November but not in June. C. balearica and Falkenbergia rufolanosa were highly toxic in both seasons and seasonal variation was very low. F. rufolanosa was the most toxic seaweed from Cabrera, whilst Halimeda tuna was never toxic.

In the sciaphilic community, 2 species were not toxic, Peyssonnelia squamaria and Palmophyllum crassum. The latter was the least toxic seaweed species analysed. P. rosamarina was toxic in November but not in June, following the same seasonal pattern as most species from the photophilic community.

\section{Hemisciaphilic community from the Medes Archipelago}

A total of 15 seaweed species from the hemisciaphilic seaweed community of Medes were analysed (Table 1). These represented 97 and $94 \%$ of algal coverage in June and November, respectively.

Species from Medes from which we collected replicates showed higher intraspecies variation of toxicity than those from Cabrera (Fig. 1), and thus standard 
Table 1. Toxicity of seaweeds from different communities of the Cabrera and Medes Archipelagos in June and November

\begin{tabular}{|c|c|c|}
\hline \multirow[t]{2}{*}{ Species and authorities } & \multicolumn{2}{|c|}{ Toxicity (gamma units) } \\
\hline & June & November \\
\hline \multicolumn{3}{|l|}{ Photophilic community (Cabrera Archipelago) } \\
\hline Amphiroa rigida Lamouroux & 0.569 & 1.459 \\
\hline Anadyomene stellata (Wulfen) C. Agardh & 1.359 & 1.776 \\
\hline Codium bursa J. Agardh & & 0.294 \\
\hline Corallina elongata Ellis \& Solander ${ }^{a}$ & 1.537 & 1.637 \\
\hline Cystoseira balearica Sauvageau & 2.033 & 1.571 \\
\hline Cystoseira compressa (Esper) Gerloff \& Nizamuddin, Ercegovici & 0.000 & 0.626 \\
\hline Dictyota dichotoma (Hudson) Lamouroux v. intricata (C. Agardh) Greville & 0.632 & 1.014 \\
\hline Dictyopteris polypodioides (Stackhouse) Batters & 0.647 & 1.722 \\
\hline Falkenbergia rufolanosa (Harvey) & 5.170 & 5.003 \\
\hline Flabellia petiolata (Turra) Nizamuddin ${ }^{\mathrm{a}}$ & 1.077 & 0.390 \\
\hline Halimeda tuna (Ellis \& Solander) Lamouroux & 0.067 & 0.061 \\
\hline Haliptilon virgatum Ellis \& Solander ${ }^{\mathrm{a}}$ & 0.947 & 1.001 \\
\hline Halopteris scoparia (Linnaeus) Sauvageau & 0.695 & 1.435 \\
\hline Lobophora variegata (Lamouroux) Womisley ${ }^{\mathrm{a}}$ & 0.603 & 0.116 \\
\hline Mesophyllum alternans (Foslie) Cabioch \& Mendoza & 0.226 & 0.556 \\
\hline Neogoniolithon brassica-florida (Dufour) Athanasiadis & 0.447 & 1.261 \\
\hline Padina pavonica (Linnaeus) Thivy & 0.399 & 0.761 \\
\hline Polysiphonia fruticulosa (Wulfen) Sprengel & 0.381 & 0.648 \\
\hline Tricleocarpa sp. & & 0.521 \\
\hline Valonia utricularis (Roth) C. Agardh & 0.622 & 2.086 \\
\hline Wurdermannia miniata (Sprengel) J. Feldmann \& Hamel & & 1.023 \\
\hline \multicolumn{3}{|l|}{ Hemisciaphilic community (Medes Archipelago) } \\
\hline Asparagopsis armata (Harvey, 1855) & 1.143 & \\
\hline Colpomenia sinuosa (Mertens ex Roth) Derbès \& Solier in Castagne & 0.849 & \\
\hline Corallina elongata Ellis \& Solander ${ }^{a}$ & 0.728 & 0.770 \\
\hline Dictyota dichotoma (Hudson) Lamouroux & 0.601 & \\
\hline Dictyota dichotoma (Hudson) Lamouroux v. intricata (C. Agardh) Greville & 0.772 & \\
\hline Dictyota fasciola (Roth) Howe & 0.359 & \\
\hline Falkenbergia rufolanosa (Harvey) ${ }^{\mathrm{a}}$ & 5.204 & 1.796 \\
\hline Flabellia petiolata (Turra) Nizamuddin ${ }^{a}$ & 0.157 & 0.432 \\
\hline Halimeda tuna (Ellis \& Solander) Lamouroux & 0.102 & 0.141 \\
\hline Halopteris filicina (Grateloup) Kützing ${ }^{\mathrm{a}}$ & 0.570 & 0.496 \\
\hline Litophyllum incrustans Philippi & 0.325 & 0.637 \\
\hline Mesophyllum alternans (Foslie) Cabioch \& Mendoza & 0.154 & 0.461 \\
\hline Padina pavonica (Linnaeus) Thivy & 0.374 & \\
\hline Peyssonnelia squamaria (Gmelin) Decaisne ${ }^{a}$ & 0.345 & 0.568 \\
\hline Taonia atomaria (Woodward) J. Agard & 0.611 & \\
\hline \multicolumn{3}{|l|}{ Sciaphilic community (Cabrera Archipelago) } \\
\hline Flabellia petiolata (Turra) Nizamuddin ${ }^{\mathrm{a}}$ & 0.555 & 0.785 \\
\hline Palmophyllum crassum (Naccari) Rabenhorst & 0.041 & 0.017 \\
\hline Peyssonnelia rosa-marina Boudouresque \& Denizot & 0.244 & 0.657 \\
\hline Peyssonnelia squamaria (Gmelin) Decaisne & 0.240 & 0.468 \\
\hline Pseudochlorodesmis furcellata (Zanardini) Børgesen ${ }^{a}$ & 0.580 & 1.221 \\
\hline
\end{tabular}

errors were higher. No species showed significant seasonal variation of toxicity.

As at Cabrera, Falkenbergia rufolanosa was the most toxic seaweed analysed. In contrast, Flabellia petiolata was non-toxic in all seasons (Fig. 2). Again as at Cabrera, Corallina elongata (Fig. 2) was toxic in both seasons and did not show seasonal variation, but its toxicity was lower in Medes. Peyssonnelia squamaria and Halopteris filicina showed mean values of toxicity slightly over 0.5 gamma only in 1 of the 2 seasons: November and June, respectively.
Comparison of species present in communities at the 2 sites

Corallina elongata and Flabellia petiolata (Fig. 2) were the onlyspecies common to both archipelagos and abundant enough to allow us to obtain replicates. The differences found in the ANOVA for C. elongata (Table 2) were due to the community factor, with the specimens from the photophilic community of Cabrera more toxic than those from the hemisciaphilic community of Medes. 


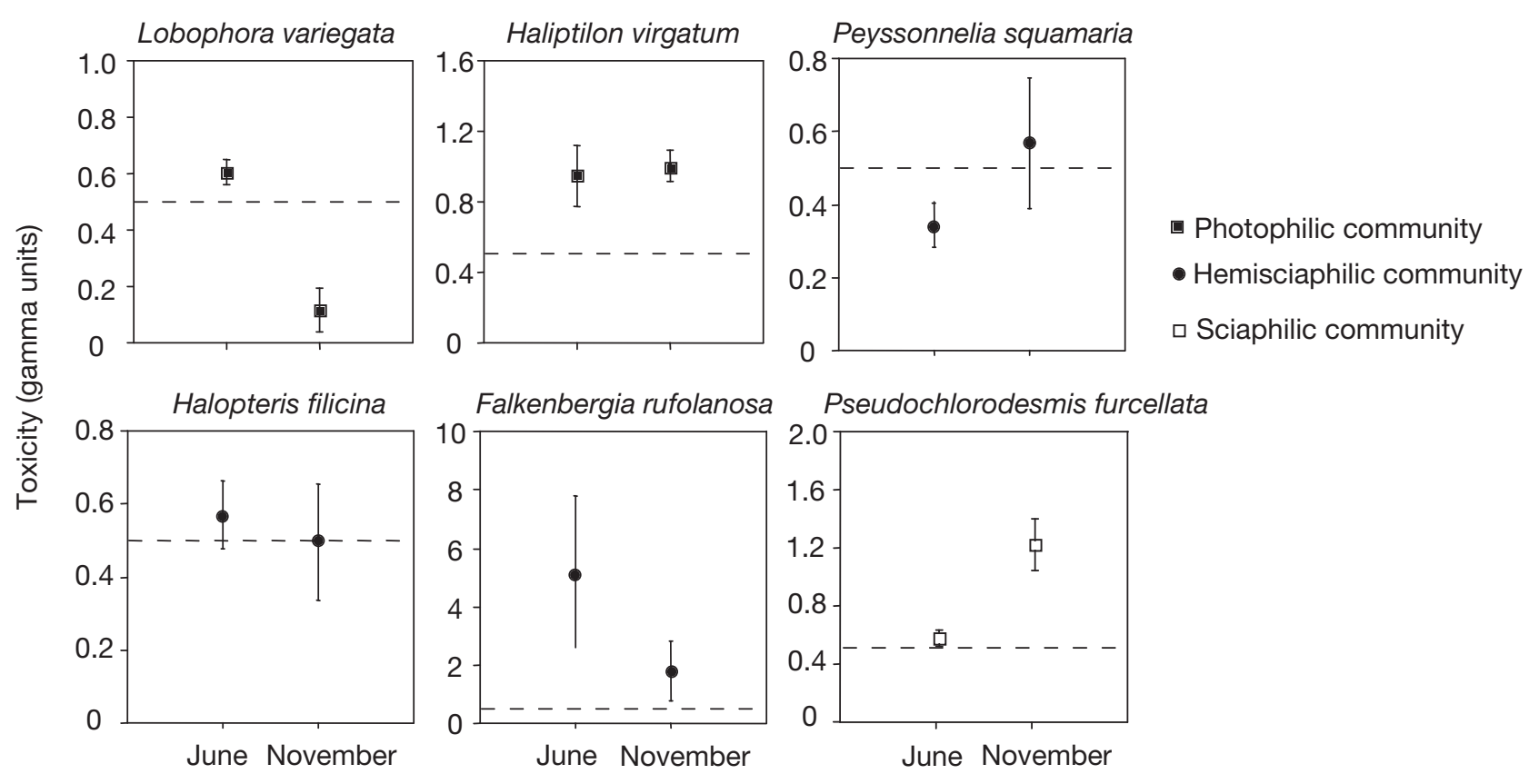

Fig. 1. Mean toxicity $(\mathrm{n}=3, \pm \mathrm{SE}$ ) of seaweed species from the photophilic, hemisciaphilic and sciaphilic communities in both seasons. Dashed line indicates the 0.5 gamma threshold, which separates toxic from non-toxic species

Toxicity of Flabellia petiolata varied differently with the season, depending on the cave community (significant interaction term, Table 2). Separate analyses in each community indicated that the species only had a significant seasonal variation of toxicity ( $\mathrm{p}<$ 0.01) in the photophilic community: higher in June than in November. When we analysed seasons separately, this species was significantly more toxic in June in the photophilic community than in the sciaphilic community of Cabrera and the hemis-

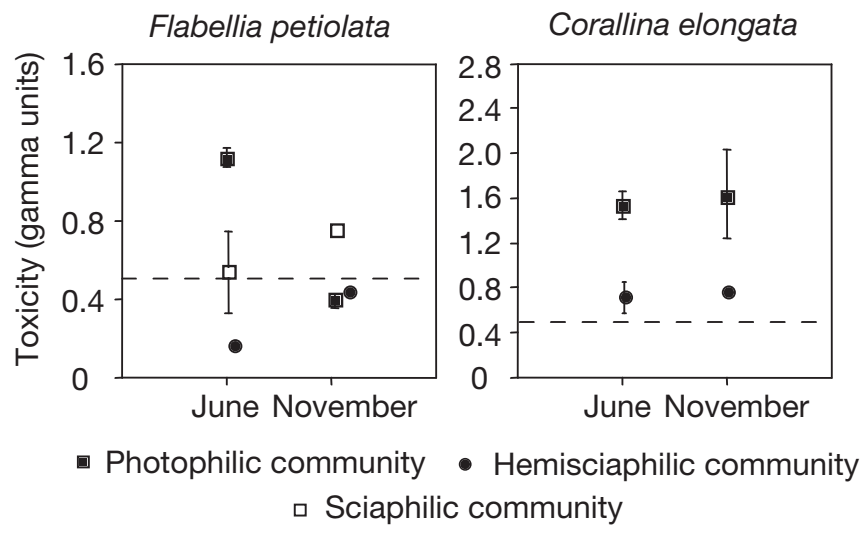

Fig. 2. Mean toxicity $(n=3, \pm S E)$ of the 2 seaweeds present in both archipelagos. Dashed line indicates the 0.5 gamma threshold, which separates toxic from non-toxic species ciaphilic communityof Medes (ANOVA $\mathrm{p}=0.007$ and Duncan post-hoc test). However, in November the species was significantly more toxic in the sciaphilic community of Cabrera than in the photophilic community of Cabrera and the hemisciaphilic community of Medes (ANOVA p $=0.034$ and Duncan post-hoc test). It should be noted that the toxicity of the species from the sciaphilic community of Cabrera and the hemisciaphilic one of Medes showed the same seasonal pattern namely toxicity was higher in November than in June.

\section{Comparison between communities for the species present in both seasons}

The number of seaweed species present in both seasons was 17 in the photophilic community and 5 in the sciaphilic community of Cabrera, and 7 in the hemisciaphilic community of Medes (Fig. 3). A 2-way ANOVA (Table 2) detected significant differences in toxicity between zones and seasons. The post-hoc Duncan test comparison indicated that the photophilic community of Cabrera was significantly more toxic than the hemisciaphilic community from Medes, and that the sciaphilic community of Cabrera did not differ significantly from either of the other 2 communities. The 3 communities showed significantly higher toxicity in November than in June. 


\section{Correlations between sea urchin and Microtox $^{\circledR}$ assays}

Fig. 4 shows the results of the regressions between the gamma units (Microtox ${ }^{\circledR}$ test) and the toxicity index from the sea urchin assay. The regression was positive $(r>0.9)$ and significant $(p<0.05)$ for all the samples analysed. Therefore, the Microtox ${ }^{\circledR}$ assay correlated well with the sea urchin test for these samples.

On the basis of all these regressions, we selected a threshold to separate toxic from non-toxic species. This threshold was 0.5 gamma units, because all the samples showed activity against sea urchin embryos at this gamma value.
Table 2. Toxicity of species and communities in June and November (2-way ANOVA). C: community, S: season

\begin{tabular}{|c|c|c|c|c|c|}
\hline Source & SS & df & MS & $F$ & $\mathrm{p}$ \\
\hline \multicolumn{6}{|c|}{ Corallina elongata (in photophilic and hemisciaphilic communities) } \\
\hline Community & 108.0 & 1 & 108.0 & 24.923 & 0.001 \\
\hline Season & 0.333 & 1 & 0.333 & 0.077 & 0.789 \\
\hline $\mathrm{C} \times \mathrm{S}$ & 0.000 & 1 & 0.000 & 0.000 & 1.000 \\
\hline Error & 34.667 & 8 & 4.333 & & \\
\hline \multicolumn{6}{|c|}{ Flabellia petiolata (in photophilic, hemisciaphilic and sciaphilic communities) } \\
\hline Community & 0.675 & 2 & 0.338 & 9.190 & 0.004 \\
\hline Season & 0.017 & 1 & 0.017 & 0.453 & 0.514 \\
\hline $\mathrm{C} \times \mathrm{S}$ & 0.883 & 2 & 0.442 & 12.020 & 0.001 \\
\hline Error & 0.441 & 12 & 0.037 & & \\
\hline \multicolumn{6}{|c|}{ Mean toxicity (all species in the 3 communities) } \\
\hline Community & 2433.9 & 2 & 1216.9 & 5.113 & 0.009 \\
\hline Season & 1171.2 & 1 & 1171.2 & 4.920 & 0.031 \\
\hline $\mathrm{C} \times \mathrm{S}$ & 62.5 & 2 & 31.2 & 0.131 & 0.877 \\
\hline Error & 12377.2 & 52 & 238.0 & & \\
\hline
\end{tabular}

\section{Qualitative approach to seaweed toxicity}

To make a qualitative interpretation of the toxicity data, all the seaweed species analysed from both archipelagos in both seasons were divided into 3 categories: those which were never-toxic in any community, archipelago or season, always-toxic ones, and those which shifted from toxic to non-toxic or vice versa in any community, archipelago or season (species occasionally toxic).

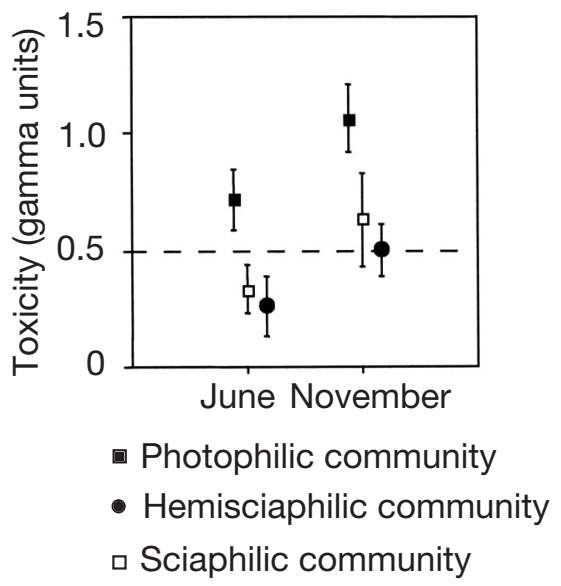

Fig. 3. Mean toxicity $( \pm \mathrm{SE})$ of seaweed species from the photophilic $(\mathrm{n}=17)$ and sciaphilic $(\mathrm{n}=5)$ communities of Cabrera and the hemisciaphilic $(n=7)$ community of Medes present in both seasons. The dashed line indicates the 0.5 gamma threshold, which separates toxic from non-toxic species
The never-toxic species category (Table 3) contained only 2 species, which represented $8 \%$ of the species analysed. The always-toxic category (Table 3 ) contained 11 species, $46 \%$ of the 24 species analysed. The occasionally toxic category also had 11 species (Table 3), $46 \%$ of the species analysed.

There was an increase (Fig. 5) in the percentage of always-toxic species and a decrease in non-toxic species from the darkest zone (the sciaphilic seaweed community) to the most illuminated zones (the photophilic seaweed community). The percentage of occasionally toxic species was higher in the sciaphilic and hemisciaphilic communities than in the photophilic community.

Chlorophyta was the group with the fewest toxic species $(60 \%)$, whereas $100 \%$ of the Phaeophyta and Rhodophyta analysed were toxic.

\section{Relationship between species toxicity and growth shapes}

We observed a similar pattern of toxicity with respect to growth shape in both archipelagos (Fig. 6, Table 4): in general sheet forms tended to be more toxic than the other morphotypes. When we pooled non-encrusting morphotypes (thick leathery, sheet and coarsely branched groups) and compared them to crustose forms, a significant difference ( $t$-test) was detected only in Cabrera: encrusting forms were less toxic than non-encrusting forms.

Significant seasonal differences ( $t$-test, $\mathrm{p}<0.05)$ of toxicity were detected only for sheet seaweeds from Cabrera Archipelago, which were more toxic in November than in June. 

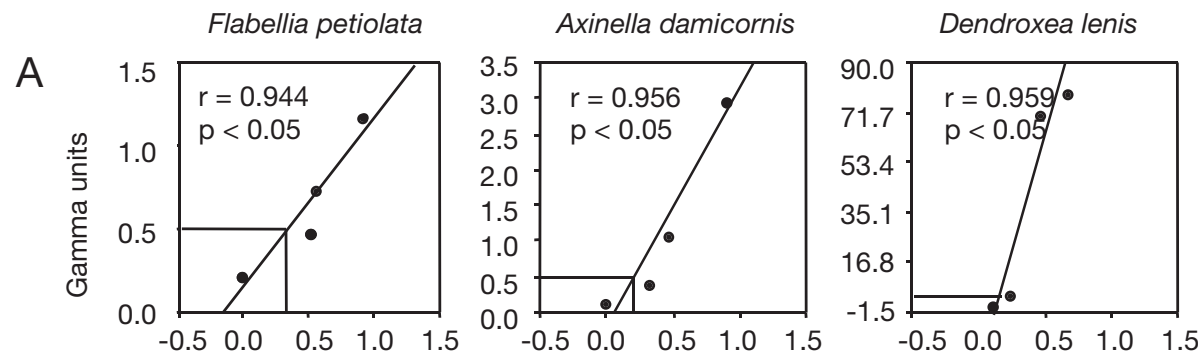

Pseudodistoma cyrnusense

Flabellia petiolata

Peyssonnelia squamaria
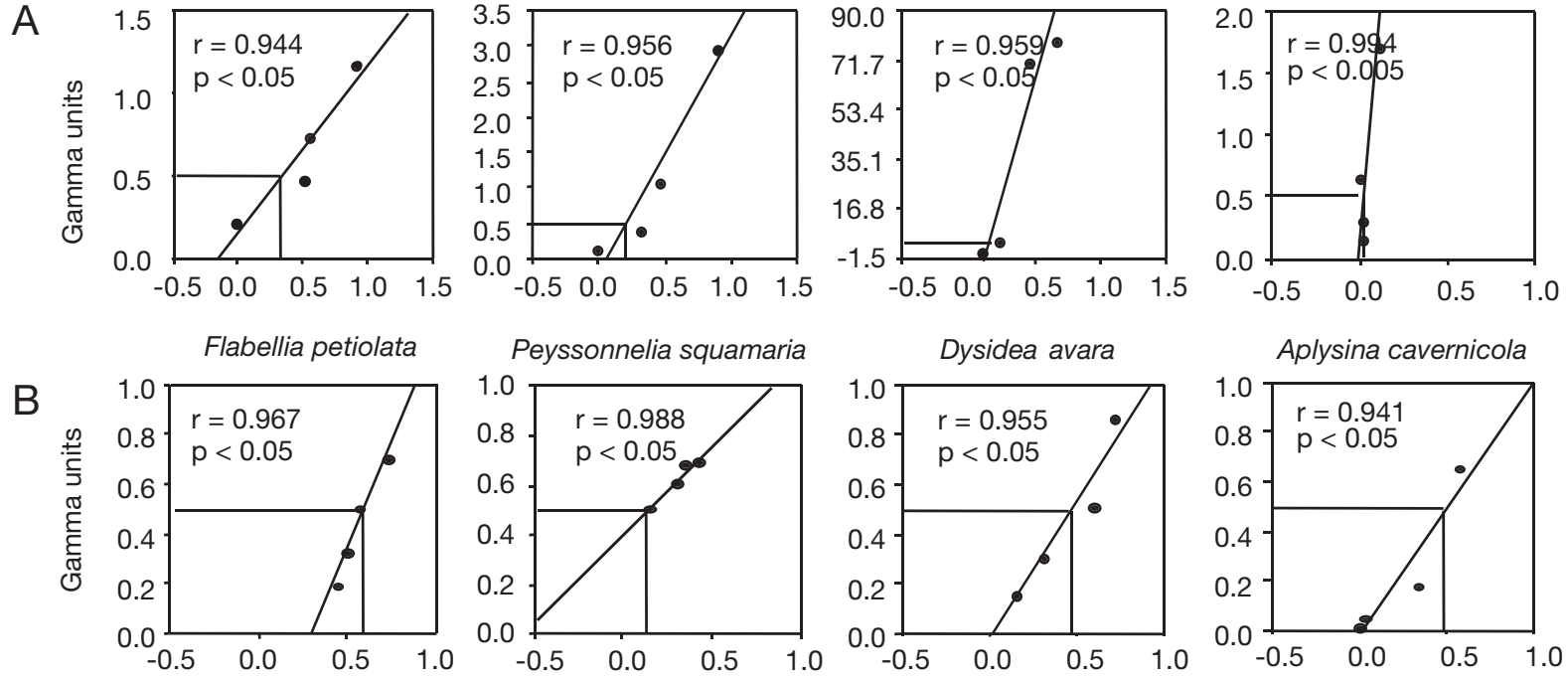

Sea-urchin toxicity index

Fig. 4. Regression analyses between gamma units (Microtox ${ }^{\circledR}$ test) and sea urchin toxicity index of species from (A) Cabrera and (B) Medes. The 0.5 gamma unit and its corresponding toxicity index indicated by lines

Table 3. Classification of seaweed species as a function of their toxic behaviour

\begin{tabular}{|c|c|c|c|}
\hline Site & Never-toxic & Occasionally toxic & Always-toxic \\
\hline Cabrera & Palmophyllum crassum & $\begin{array}{l}\text { Cystoseira compressa } \\
\text { Lobophora variegata } \\
\text { Neogoniolithon brassica-florida } \\
\text { Peyssonnelia rosamarina } \\
\text { Polysiphonia fruticulosa }\end{array}$ & $\begin{array}{l}\text { Amphiroa rigida } \\
\text { Anadyomene stellata } \\
\text { Cystoseira balearica } \\
\text { Dictyopteris polypodioides } \\
\text { Halopteris scoparia } \\
\text { Haliptilon virgatum } \\
\text { Pseudochlorodesmis furcellata } \\
\text { Valonia utricularis }\end{array}$ \\
\hline Medes & & $\begin{array}{l}\text { Halopteris filicina } \\
\text { Litophyllum incrustans }\end{array}$ & \\
\hline Common to both sites & Halimeda tuna & $\begin{array}{l}\text { Flabellia petiolata } \\
\text { Mesophyllum alternans } \\
\text { Padina pavonica } \\
\text { Peyssonnelia squamaria }\end{array}$ & $\begin{array}{l}\text { Corallina elongata } \\
\text { Dictyota dichotoma var. intricata } \\
\text { Falkenbergia rufolanosa }\end{array}$ \\
\hline
\end{tabular}

\section{Seasonal changes in coverage and toxicity}

The spatial representation of the relationship between change in toxicity and change in coverage of seaweed species in June and November is represented in Fig. 7A. Fig. 7B represents the same relationship but excludes the species Lobophora variegata since its high change in coverage compared to the other species made the spatial representation of the remaining species cluttered.

In Quadrant I there were 6 species, 11 in Quadrant II, only 2 in Quadrant III and 4 in Quadrant IV. The pattern deviated significantly from an expected ran- dom distribution across quadrants $(p<0.05)$. It is interesting to note that many species of Quadrant II, which increased both coverage and toxicity in November compared to June, were encrusting forms: Mesophyllum alternans $(9,12)$, Neogoniolithon brassica-florida (11), Peyssonnelia rosa-marina (8) and $P$. squamaria (13). The higher coverage of these species in November (especially $N$. brassica-florida and $M$. alternans) may be due to the disappearance of the canopy layer that covered them in June, so that the increase in coverage observed may not be due to true growth. Thus, these results should be taken with caution. 


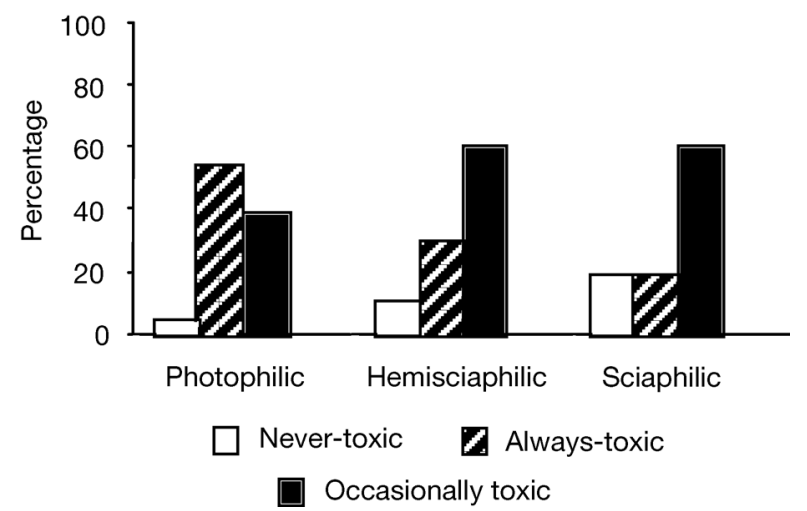

Fig. 5. Percentage of seaweed species from sampled communities in the 3 established categories of toxicity

The 6 species depicted in Quadrant I increased slightly in toxicity while decreasing in area from June to November. The only 2 species in Quadrant III, i.e. Falkenbergia rufolanosa (18) and Cystoseira balearica (19) from Cabrera, also decreased slightly in both coverage and toxicity in November.

Finally, 2 of the 4 species from Quadrant IV, i.e. Falkenbergia rufolanosa (21) and Halopteris filicina (20), both from Medes, showed a discrete increase in coverage from June to November as compared to Flabellia petiolata (22) and Lobophora variegata (Fig. 7A). The 2 latter species have tropical affinities (Ballesteros 1993) and are characterised by maximum growth at the end of summer, which can explain their higher coverage in November.

\section{DISCUSSION}

Many studies have demonstrated that seaweeds are an important source of bioactive secondary metabolites (Burkholder et al. 1960, Hornsey \& Hide 1974, 1976, Naqvi et al. 1980, Reichelt \& Borowitzka 1983, Hodgson 1984, Paul \& Fenical 1986, 1991, Van Alstyne \& Paul 1988, Munro et al. 1991, Hay 1996). Our results showed that $87 \%$ of the seaweed species analysed were toxic (mean toxicity higher than 0.5 gamma value) in at least 1 season, archipelago or community.

At Cabrera $64 \%$ of the seaweed species analysed were more toxic in November than in June, and only 3 species $(7.3 \%)$ showed the opposite pattern (Cystoseira balearica, Flabellia petiolata and Lobophora variegata, all 3 from the

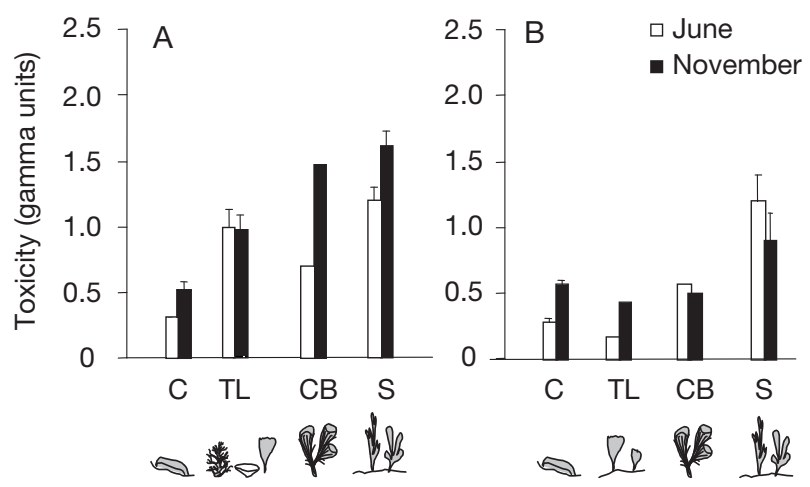

Fig. 6. Seasonal variation of natural toxicity in seaweeds depending on their growth shape. (A) Cabrera and (B) Medes Archipelagos. Growth shapes: C, crustose groups; TL, thick, leathery group (note that this group is separated into 3 different morphologies); $\mathrm{JC}$, jointed calcareous group; $\mathrm{CB}$, coarsely branched group. For bars without SD, only 1 species was analysed

photophilic community). Moreover, 10 species of those that were toxic in November were non-toxic or at the limit of the 0.5 gamma value in June.

In summary, most algal species from Cabrera had marked seasonal changes in toxicity, which increased from spring to autumn. In contrast, the species from Medes showed greater intraspecies variability in toxicity but had no significant seasonal variation of toxicity.

The good correlations between the results of Microtox ${ }^{\circledR}$ and the sea-urchin tests indicate that these toxicities may have an effect on both prokaryotic and

Table 4. Coverage and growth shape of seaweed species. PC, HC and SC represent photophilic, hemisciaphilic and sciaphilic communities, respectively. Growth forms: (C) crustose; (TL) thick, leathery; (S) sheet; (CB) coarsely branched

\begin{tabular}{|lccc|}
\hline \multirow{2}{*}{ Species } & \multirow{2}{*}{ Growth form } & \multicolumn{2}{c|}{ Coverage (\%) } \\
& & June & November \\
\hline Corallina elongata (PC/HC) & $\mathrm{S}$ & $0.4 / 2.37$ & $0.43 / 11.27$ \\
Cystoseira balearica (PC) & $\mathrm{TL}$ & 10.63 & 2.06 \\
Dictyopteris polypodioides (PC) & $\mathrm{S}$ & 2.73 & 2.94 \\
Dictyota dichotoma v. intricata (PC) & $\mathrm{S}$ & 23.81 & 2.51 \\
Falkenbergia rufolanosa (PC/HC) & $\mathrm{S}$ & $0.61 / 33.35$ & $0.22 / 45.20$ \\
Flabellia petiolata (PC/HC/SC) & $\mathrm{TL}$ & $0.09 / 0.56 / 5.39$ & $0.54 / 2.27 / 8.34$ \\
Haliptilon virgatum (PC) & $\mathrm{S}$ & 9.19 & 36.95 \\
Halopteris filicina (HC) & $\mathrm{CB}$ & 1.36 & 3.41 \\
Halopteris scoparia (PC) & $\mathrm{CB}$ & 15.38 & 1.30 \\
Litophyllum incrustans (HC) & $\mathrm{C}$ & 1.78 & 1.47 \\
Lobophora variegata (PC) & $\mathrm{C}$ & 0.18 & 5.48 \\
Mesophyllum alternans (PC/HC) & $\mathrm{C}$ & $0.49 / 2.65$ & $2.11 / 11.35$ \\
Neogoniolithon brassica-florida (PC) & $\mathrm{C}$ & 7.44 & 28.59 \\
Padina pavonica (PC) & $\mathrm{TL}$ & 22.89 & 6.47 \\
Peyssonnelia rosa-marina (SC) & $\mathrm{C}$ & 32.31 & 44.90 \\
Peyssonnelia squamaria (HC/SC) & $\mathrm{C}$ & $0.81 / 13.38$ & $3.34 / 9.47$ \\
Pseudochlorodesmis furcellata (SC) & $\mathrm{S}$ & 1.09 & 0.2 \\
\hline
\end{tabular}




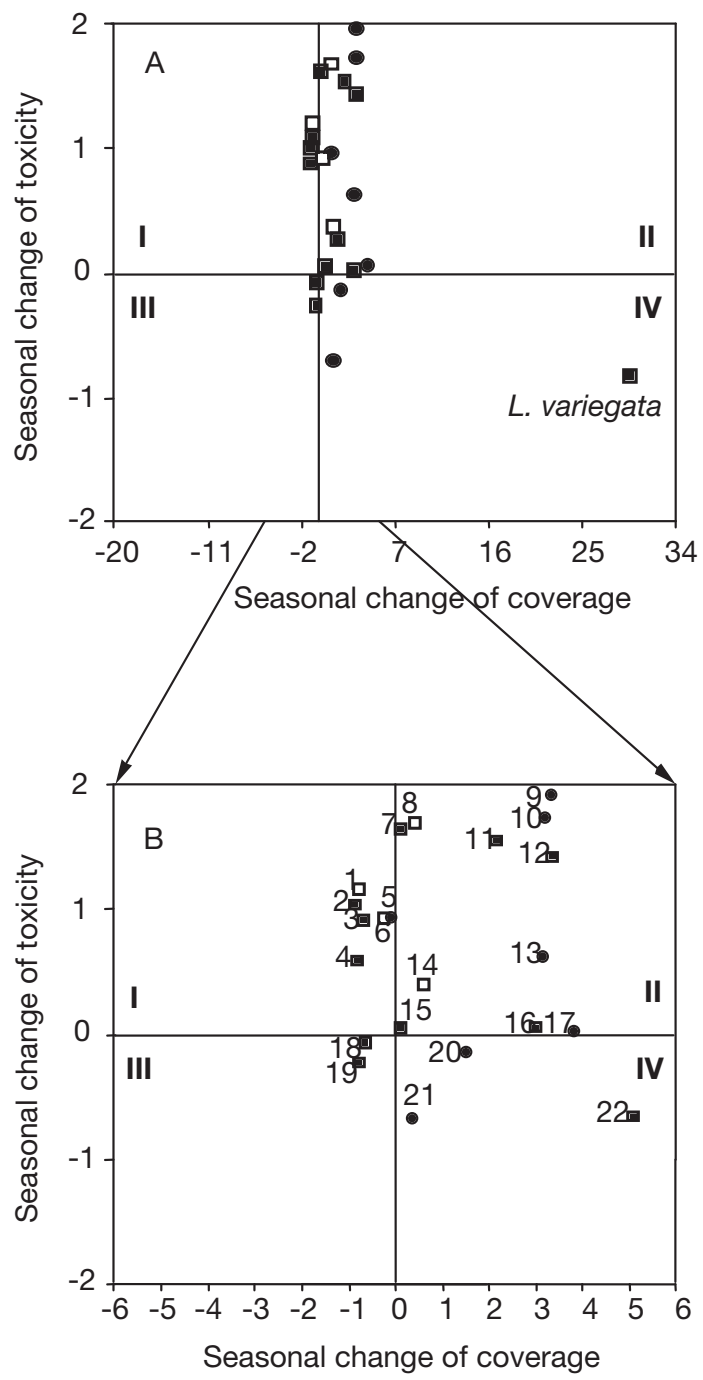

Fig. 7. Relationship between seasonal change of toxicity and coverage for seaweed species from the photophilic and sciaphilic communities of Cabrera and the hemisciaphilic community of Medes. Note scale difference between (A) and (B). For full species names see Table 1. Note deletion of $L$. variegata from (B)
Photophilic community

Sciaphilic community

- Hemisciaphilic community

Photophilic community

2. H. scoparia

3. P. pavonica

4. D. dicothoma var. intricata

7. D. polypodioides

11. N. brassica-florida

12. M. alternans

15. C. elongata

16. H. virgatum

18. F. rufolanosa

19. C. balearica

22. F. petiolata

Sciaphilic community

1. P. furcellata

6. P. squamaria

8. P. rosa-marina

14. F. petiolata

Hemisciaphilic community

5. L. incrustans

9. M. alternans

10. F. petiolata

13. P. squamaria

17. C. elongata

20. H. filicina

21. F. rufolanosa investigation, would be necessary to confirm the ecological trends here reported, and would represent a further step of the study.

On comparison of the percentage of species belonging to each of the established toxic categories (always-toxic, never-toxic and occasionally toxic) in the 3 seaweed communities, differences became clear. The decrease in light received from photophilic to sciaphilic communities coincided with a marked decrease in the always-toxic species and an increase in both nevertoxic and occasionally toxic species. This positive correlation between light and toxicity might be due to an optimization of the species fitness under high irradiance. However, nitrogen can be limiting in the Cabrera waters (Vives 1993). The carbon-nutrient balance hypothesis (Cronin \& Hay 1996) suggests that part of the differences in toxicity detected within species between Cabrera and Medes could be due to nitrogen limitation in Cabrera, which would direct excess of photosynthates toward the production of chemical defences. If this hypothesis is right, then these defences should be C-based rather than N-based.

A higher allocation of the available resources to defence in environments where seaweeds are limited by nutrients is consistent with the higher mean toxicity found in species from Cabrera. In our design, the community factor cannot be separated from the geographic area factor, as our 3 communities belong to 2 different areas. However, in the 2 Cabrera communities, the pattern of a decrease in toxicity from the photophilic to the sciaphilic community still holds true and cannot be explained on the basis of resource allocation hypotheses because there were no significant differences in nitrogen concentration between the 2 communities (Martí et al. 2004). As in the comparison between archipelagos, the species from a less lighted community of Cabrera (sciaphilic community) are less toxic than those of the photophilic community. This seems to be a consistent pattern in Mediterranean communities, because Uriz et al. (1991) also found lower antibacterial activity in species from sciaphilic seaweed communities than in those from photophilic ones. experiments, which were not the aim of the present However, from these laboratory tests, we can only
speculate about their possible effects in the field. Field

eukaryotic cells and may have an ecological role as deterrent, antifouling or space competition mechaAn do their antimitotic and cytotoxic propertie city since several toxic species (according to Micr results) were also deterrent when given to fish and sea urchins (Hay et al. 1998) while others deter amphipods from grazing (Hay et al. 1998, Schnitzler et al. 1998). However, from these laboratory tests, we can only
speculate about their possible effects in the field. Field 
In our study, Phaeophyta and Rhodophyta contained the most toxic species and the highest percentage of toxic species, followed by Chlorophyta. These percentages contrast with the results from a previous screening against pathogenic microbes in which Chlorophyta contained the highest number of active species (Ballesteros et al. 1992). However, in most previous studies, Rhodophyta and Phaeophyta were the 2 most bioactive groups (Barbagallo et al. 1979, Caccamese et al. 1981, 1985, Padmakumar \& Ayyakkannu 1997). Furthermore, Harper et al. (2001) listed the known secondary metabolites from the 3 groups of seaweed and showed that $51 \%$ of the compounds described up to now belonged to Rhodophyta, $41 \%$ to Phaeophyta, and only $8 \%$ to Chlorophyta. Therefore, the activity measured by Microtox ${ }^{\circledR}$ coincided quite well with most previous studies and reflects the patterns of abundance of bioactive compounds in seaweeds.

Some of the species that did not show toxicity in our study were reported as toxic in previous screenings, or vice versa (Porzi \& Minelli 1975, Caccamese \& Azzolina 1979, Caccamese et al. 1980, 1981, 1985, Pesando \& Caram 1984, Ballesteros et al. 1992). Differences in extraction procedures and bioassay methods may account for these differences. However, the geographic, seasonal or spatial variation in toxicity of seaweeds found in this study and reported previously (Hornsey \& Hide 1976, Caccamese et al. 1980, Meyer \& Paul 1992, Pavia \& Aberg 1996, Padmakumar \& Ayyakkannu 1997, Van Alstyne et al. 1999, Wright et al. 2000) may also contribute to different outcomes in toxicity assessment.

When we studied the relationship between toxicity and growth shapes, we observed that the non-encrusting (thick, leathery, sheet and coarsely branched groups) forms tended to be more toxic than the crustose forms. This pattern may reflect a higher investment in chemical defences in those algae (sheets) more susceptible to grazing. Of course, other defence mechanisms (e.g. physical defences such as calcification or leathery consistency) may act to prevent grazing by herbivores in seaweeds. This can explain why Littler et al. (1983) reported that functional-form groups of stony, tough or leathery-rubbery texture were the forms most resistant to herbivores. Although seasonal differences of toxicity were general in the various forms of seaweeds analysed, these differences were only significant in non-encrusting forms from Cabrera, where seaweeds toxicity was higher in November than in June.

At a community level as well as at species level, there was an increase in toxicity for most species in November compared to June (i.e. those species in Quadrants I and II in Fig. 7B), that may be attributed to a physiological process of ageing, but also to a lower requirement of photosynthates for maintenance or resource acquisiton, which would produce a shift in allocation of resources from growth or reproduction to production of toxic compounds. Following the cycles reported for photophilic communities in the Mediterranean (Ballesteros 1991), the photophilic seaweed community of Cabrera was in a diversification phase in November (Martí 2002). After a phase of high growth rates and reproduction in summer, many species had smaller coverage and lower growth rates in November, and may allocate more resources to synthesis of secondary metabolites than in June, when the energy should be devoted to somatic growth and reproduction. This behaviour matches Grime's plant strategy model (Grime 1979), slightly modified by Cronin (2001), which states that, when growth and reproduction occurred, a lower portion of the acquired resources can be allocated to chemical defences.

Conversely, the species Lobophora variegata from the photophilic community of Cabrera and, to a lesser extent, Flabellia petiolata, increased in coverage from June to November (warmest months in the Mediterranean) possibly because they have tropical affinities (Ballesteros 1993) and, as it would be expected according to Grime's theory, they experienced a decrease of toxicity during the same period. Consequently, our results suggest that Grime's model could explain the seasonal variation of toxicity found in non-encrusting algae.

Increased levels in production of chemical defences associated with decreases in growth, as those reported here, survival or reproduction processes have already been described in previous studies for terrestrial plants (Berenbau et al. 1986, Coley 1986) and for the seaweed Fucus vesiculosus (Yates \& Peckol 1993).

As for the encrusting algae with a weak seasonal variation of toxicity, it is difficult to ascribe toxicity variation to changes in coverage because quantifying growth from the pictures may be inaccurate, as the change in coverage recorded may have been partially due to the canopy layer that covered them in June but not in November and, besides, they usually have very slow growth rates (Garrabou \& Ballesteros 2000).

This study clearly shows a spatial and temporal variation of toxicity in several Mediterranean seaweeds. It also illustrates that toxicity varies intra-species as well as inter-species as a function of community or season, which points to the role of abiotic and biotic factors in the production of chemical defences by seaweeds. However, this variability should be addressed experimentally in the future by means of transplantation experiments, to verify whether there is a cause/effect relationship and to find the concrete factors that affect toxic metabolites production. 
Acknowledgements. This research was funded by projects Mar95-1764 and REN2001-2312 of the Spanish Government and by the Interreg IIIA-1-72-E project of the European Union. R.M. was supported by a postgraduate fellowship from the Catalan Government and a post-doctoral fellowship from the Spanish Government. We acknowledge the logistic support and permits for diving and collecting granted by the Cabrera National Park (Balearic Islands). We particularly thank E. Ballesteros for help with the sampling, elaboration of inventories, outlining the slides and identification of species. We are also grateful to E. Cebrian, N. Sant and M. Ballesteros for their help with the sampling and to G. Agell, M. Bardají and N. Llambi for help in the laboratory. Comments from anonymous reviewers improved the final version of the manuscript.

\section{LITERATURE CITED}

Ballesteros E (1991) Structure and dynamics of north-western Mediterranean phytobenthic communities: a conceptual model. Oecol Aquatica 10:223-242

Ballesteros E (1993) Algues bentòniques i fanerògames marines. In: Alcover JA, Ballesteros E, Fornós JJ (eds) Història Natural de 1'Arxipèlag de Cabrera. CSIC-Edit Moll, Mallorca, p 503-530

Ballesteros E, Martin D, Uriz MJ (1992) Biological activity of extracts from some Mediterranean macrophytes. Bot Mar 35:481-485

Barbagallo C, Cormaci M, Furnari G, Gismondo R, Majorana G, Toscano MA (1979) Attivita antibatterica di estratti di alghe marine delle coste orientali della Sicilia: I contributo: 1-5. Pubbl Ist Bot Univ Catania

Becerro MA, Uriz MJ, Turon X (1995) Measuring toxicity in marine environment: critical appraisal of three commonly used methods. Experientia 51:414-418

Berenbau MR, Zangerl AR, Nitao JK (1986) Constraints on chemical co-evolution: wild parsnips and the parsnip webworm. Evolution 40:1215-1228

Botsford JL (2002) A comparison of ecotoxicological tests. ATLA Altern Lab Anim 30:539-550

Burkholder PR, Burkholder LM, Almodovar LR (1960) Antibiotic activity of some marine algae of Puerto Rico. Bot Mar 2:149-156

Burridge LE, Doe K, Haya K, Jackman PM, Lindsay G, Sitko V (1999) Chemical analyses and toxicity tests on sediments under salmon net pens in the Bay of Fundy. Can Tech Rep Fish Aquat Sci 2291:1-33

Caccamese S, Azzolina R (1979) Screening for antimicrobial activities in marine algae from Eastern Sicily. Planta Med 37:333-339

Caccamese S, Azzolina R, Furnari G, Cormaci M, Grasso S (1980) Antimicrobial and antiviral activities of extracts from Mediterranenan algae. Bot Mar 23:285-288

Caccamese S, Azzolina R, Furnari G, Cormaci M, Grasso S (1981) Antimicrobial and antiviral activities of some marine algae from Eastern Sicily. Bot Mar 24:365-367

Caccamese S, Toscano RM, Furnari G, Cormaci M (1985) Antimicrobial activities of red and brown algae from Southern Italy coast. Bot Mar 28:505-507

Chénieux JC, Verbist JF, Biard JF, Clement E, Le Boterff J, Maupas P, Lecocqu M (1980) Algues Fixées de la Côte Atlantique Française contenant des substances antimitotiques. Planta Med Suppl:152-162

Coley PD (1986) Costs and benefits of defence by tannins in a neotropical tree. Oecologia 70:238-241
Conover WO, Iman RL (1981) Rank transformation as a bridge between parametric and nonparametric statistics. Am Stat 35:124

Cronin G (2001) Resource allocation in seaweeds and marine invertebrates: chemical defense patterns in relation to defense theories. In: McClintock JB, Baker BJ (eds) Marine chemical ecology. CRC press, Boca Raton, FL, p 325-353

Cronin G, Hay ME (1996) Within-plant variation in seaweed palatability and chemical defenses: optimal defense theory versus the growth-differentiation balance hypothesis. Oecologia 105:361-368

Del Valls TA, Lubian LM, Forja JM, Gomez-Parra A (1997) Comparative ecotoxicity of interstitial waters in littoral ecosystems using Microtox registered and the rotifer Brachionus plicatilis. Environ Toxicol Chem 16:2323-2332

de Nys R, Coll JC, Price IR (1991) Chemically mediated interactions between the red alga Plocamium hamatum and the soft coral Sinularia cruciata (Alcyonacea). Mar Biol 108:315-320

de Nys R, Dworjanyn SA, Steinberg PD (1998) A new method for determining surface concentrations of marine natural products on seaweeds. Mar Ecol Prog Ser 162:79-87

de Nys R, Steinberg PD, Willemsen P, Dworjanyn SA, Gabelish CL, King RJ (1995) Broad spectrum effects of secondary metabolites from the red alga Delisea pulchra in antifouling assays. Biofouling 8:259-271

Dworjanyn SA, de Nys R, Steinberg PD (1999) Localisation and surface quantification of secondary metabolites in the red alga Delisea Pulchra. Mar Biol 133:727-736

Fletcher RL (1975) Heteroantagonism observed in mixed algal cultures. Nature 253:169-178

Garrabou J, Ballesteros E (2000) Growth of Mesophyllum alternans and Lithophyllum frondosum (Corallinales, Rhodophyta) in the north-western Mediterranean. Eur J Phycol 35:1-10

Ghirardini AV, Birkemeyer T, Novelli AA, Delaney E, Pavoni B, Ghetti PF (1999) An integrated approach to sediment quality assessment: the Venetian lagoon as a case study. Aquat Ecosyst Health Manag 2:435-447

Grime JP (1979) Plant strategies and vegetation process. John Wiley, New York

Harlin MM (1987) Allelopathy in marine macroalgae. CRC Crit Rev Plant Sci 5:237-249

Harper MK, Bugni TS, Copp BR, James RD and 7 others (2001) Introduction to the chemical ecology of marine natural products. In: McClintock JB, Baker BJ (eds) Marine chemical ecology. Marine Science Series. Boca Raton, FL, p 3-69

Hay ME (1996) Marine chemical ecology: What's known and what's next? J Exp Mar Biol Ecol 200:103-134

Hay ME, Duffy JE, Pfister CA, Fenical W (1987) Chemical defenses against different marine herbivores: Are amphipods insect equivalents? Ecology 68:1567-1580

Hay ME, Renaud PE, Fenical W (1988) Large mobile versus small sedentary herbivores and their resistance to seaweed chemical defenses. Ecology 75:246-252

Hay ME, Piel J, Boland W, Schnitzler I (1998) Seaweed sex pheromones and their degradation products frequently supress amphipod feeding but rarely suppress sea urchin feeding. Chemoecology 8:91-98

Helleburst JA (1975) Extracellular products. In: Stewart, WD P (ed) Algal physiology and biochemistry. Blackwell Scientific Publications, Oxford, p 838-863

Henríquez P, Candia A, Norambuena R, Silva M, Semelman R (1979) Antibiotic properties of marine algae. II. Screening of Chilean marine algae for antimicrobial activity. Bot Mar 12:451-453 
Hodgson LM (1984) Antimicrobial and antineoplastic activity in some South Florida seaweeds. Bot Mar 27:387-390

Hornsey IS, Hide D (1974) The production of antimicrobial compounds by British marine algae. I. Antibiotic-producing marine algae. Br Phycol J 9:353-361

Hornsey IS, Hide D (1976) The production of antimicrobial compounds by British marine algae. II. Seasonal variation in production of antibiotics. Br Phycol J 11:63-67

Kjelleberg S, Steinberg PD, Givskov M, Gram L, Manefield M, de Nys R (1997) Do marine natural products interfere with prokaryotic AHL regulatory systems? Aquat Microb Ecol 13:85-93

Littler MM, Littler DS (1980) The evolution of thallus form and survival strategies in benthic marine macroalgae: field and laboratory tests of a functional form model. Am Nat 116:25-43

Littler MM, Littler DS, Taylor PR (1983) Evolutionary strategies in a tropical barrier reef system: funtional-form groups of marine macroalgae. J Phycol 19:229-237

Margalef R (1977) Ecología. Ediciones Omega, Barcelona

Martí R (2002). Spatial and temporal variation of the natural toxicity in benthic communities of Mediterranean caves. $\mathrm{PhD}$ thesis, University of Barcelona, Barcelona

Martí R, Fontana A, Uriz MJ, Cimino G (2003) Quantitative assessment of natural toxicity in sponges: toxicity bioassay versus compound quantification. J Chem Ecol 29: 1283-1294

Martí R, Uriz MJ, Ballesteros E, Turon X (2004) Benthic assemblages in two Mediterranean caves: species diversity and coverage as a function of abiotic parameters and geographic distance. J Mar Biol Assoc UK 84:557-572

Martín D, Uriz MJ (1993) Chemical bioactivity of Mediterranean benthic organisms against embryos and larvae of marine invertebrates. J Exp Mar Biol Ecol 173:11-27

Meyer KD, Paul VJ (1992) Intraplant variation in secondary metabolite concentration inthree species of Caulerpa (Chlorophyta: Caulerpales) and its effects on herbivorous fishes. Mar Ecol Prog Ser 82:249-257

Munro MHG, Luibrand RT, Blunt JW (1991) The search for antiviral and anticancer compounds from marine organisms. In: Scheuer PJ (ed) Bioorganic marine chemistry. Springer Verlag, Berlin, p 93-176

Naqvi SW, Solimabi A, Kamat SY, Fernandes L, Reddy CVG, Bhakuni DS, Dhawan BN (1980) Screening of some marine plants from the Indian coast for biological activity. Bot Mar 24:51-55

Padmakumar K, Ayyakkannu K (1997) Seasonal variation of antibacterial and antifungal activities of the extracts of marine algae from southern coasts of India. Bot Mar 40:507-515

Paul VJ, Fenical W (1986) Chemical defense in tropical green algae, order Caulerpales. Mar Ecol Prog Ser 33:255-264

Paul VJ, Fenical W (1991) Natural products chemistry and chemical defense in tropical marine algae of the phylum Chlorophyta. In: Scheuer PJ (ed) Bioorganic marine chemistry. Springer Verlag, Berlin, p 1-29

Pavia H, Aberg P (1996) Spatial variation in polyphenolic content of Ascophyllum nodosum (Fucales, Phaeophyta). Hydrobiologia 326/327:199-203

Pedersen F, Bjoernestad E, Andersen HV, Kjolholt J, Pool C (1998) Characterization of sediments from Copenhagen Harbour by use of biotests. Water Sci Technol 37:233-240

Pesando D, Caram B (1984) Screening of marine algae from the French Mediterranean coast for antibacterial and antifungal activity. Bot Mar 27:381-386

Porzi G, Minelli E (1975) Attivita antibatterica e presenza di mercurio in dodici specie di alghe marine. Boll Soc Ital Biol Sper 51:1591-1595

Potvin C, Roff DA (1993) Distribution-free and robust statistical methods: viable alternatives to parametric statistics? Ecology 74:1617-1628

Ragan MA (1976) Physodes and the phenolic compounds of brown algae. Composition and significance of physodes in vivo. Bot Mar 19:145-154

Ragan MA, Glombitza KW (1986) Phlorotannins, brown algal polyphenols. Prog Phycol Res 4:145-154

Reichelt JL, Borowitzka (1983) Antimicrobial activity from marine algae: results of a large-screening programme. Proc Int Seaweed Symp 11:158-168

Sabaliunas D, Lazutka JR, Sabaliuniene I (2000) Acute toxicity and genotoxicity of aquatic hydrophobic pollutants sampled with semipermeable membrane devices. Environ Pollut 109:251-265

Schmitt TM, Hay ME, Lindquist N (1995) Constraints on chemically mediated coevolution: multiple functions for seaweed secondary metabolites. Ecology 76:107-123

Schnitzler I, Boland W, Hay ME (1998) Organic sulfur compounds from Dictyopteris spp. (Phaeophyceae) deter feeding by an herbivorous amphipod (Amphitoe longimana) but not by an herbivorous sea urchin (Arbacia punctulata). J Chem Ecol 24:1715-1732

Schnitzler I, Pohnert G, Hay ME, Boland W (2001) Chemical defense of brown algae (Dictyopteris spp.) against the herbivorous amphipod Ampithoe longimana. Oecologia 126: 515-521

Stachowicz JJ, Lindquist N (1997) Chemical defense among hydroids on pelagic Sargassum: predator deterrence and absorption of solar UV radiation by secondary metabolites. Mar Ecol Prog Ser 155:115-126

Uriz MJ, Martin D, Turon X, Ballesteros E, Hughes R, Acebal C (1991) An approach to the ecological significance of chemically mediated bioactivity in Mediterranean benthic communities. Mar Ecol Prog Ser 70:175-188

Uriz MJ, Turon X, Becerro MA, Galera J, Lozano J (1995) Patterns of resource allocation to somatic, defensive, and reproductive functions in the Mediterranean encrusting sponge Crambe crambe. Mar Ecol Prog Ser 124:159-170

Vadas RL (1979) Seaweeds: an overview, ecological and economic importance. Experientia 35:429-433

Van Alstyne KL, Paul VJ (1988) The role of secondary metabolites in marine ecological interactions. Proc 6th Int Coral Reef Symp 1:175-186

Van Alstyne KL, McCarthy JJ III, Hustead CL, Duggins DO (1999) Geographic variation in polyphenolic levels of Northeastern Pacific kelps and rockweeds. Mar Biol 133:371-379

Vives F (1993) Aspectes hidrogràfics i planctònics dels voltants de l'Arxipèlag de Cabrera. In: Alcover J A, Ballesteros E, Fornós J J (eds) Història Natural de l'Arxipèlag de Cabrera. CSIC-Edit Moll Mallorca, p 487-502

Wolk (1968) Role of bromine in the formation of the refractile inclusions of the vesicle cells of the Bonnemaisonales (Rhodophyta). Planta 78:371-378

Wright JT, de Nys R, Steinberg PD (2000) Geographic variation in halogenated furanones from the red alga Delisea pulchra and associated herbivores and epiphytes. Mar Ecol Prog Ser 207:227-241

Yates J, Peckol P (1993) Effects of nutrient availability and herbivory on polyphenolics in the seaweed Fucus vesiculosus. Ecology 74:1757-1766

Zar JH (1984) Biostatistical analysis, 2nd edn. Prentice-Hall International, Englewood Cliffs, NJ

Submitted: October 7, 2003; Accepted: July 15, 2004

Proofs received from author(s): October 21, 2004 